\title{
ANALISIS GENDER DALAM KEHIDUPAN KELUARGA NELAYAN DI KECAMATAN PANGANDARAN KABUPATEN CIAMIS
}

\author{
Rani Andriani Budi Kusumo ${ }^{1}$, Anne Charina ${ }^{2}$, Gema Wibawa Mukti ${ }^{3}$ \\ Staf Pengajar Program Studi Agribisnis Fakultas Pertanian \\ Universitas Padjadjaran
}

\begin{abstract}
The study, entitled "Gender Analysis in Families Life Fishermen in Pangandaran Ciamis district" was conducted over eight months. The purpose of this study was to: 1) Assess the socio-economic characteristics of fishermen families in the District of Pangandaran Ciamis district.; 2) analyze the pattern of decision-making and the division of labor between husband and wife in a family of fishermen in the domestic sector and the public.

This study uses survey method. The respondents consisted of 30 families of fishermen. Data were analyzed descriptively to create a systematic picture, factual and accurate statement of the facts, properties and relationships studied phenomenon objectively.

The results showed that the level of education the majority of families of fishermen included in the low category. Perceptions of gender on family fishing generally illustrates that the main task the wife is the household, but it may help her husband in making a living family, while earning a living primary responsibility remains the task of the husband. Decision-making concerning the domestic activities and the public in a family of fishermen do not follow a particular pattern is specifically focused on the husband or wife, but it has a pattern that spreads between husband and wife. The task sharing concerning the domestic activities mostly done by the wife. While the division of labor associated with public activities spread between husband and wife.
\end{abstract}

Keywords: gender, task sharing management, decision-making pattern

\begin{abstract}
ABSTRAK
Penelitian yang berjudul "Analisis Gender dalam Kehidupan Keluarga Nelayan di Kecamatan Pangandaran Kabupaten Ciamis" ini dilakukan selama delapan bulan. Tujuan dari penelitian ini adalah untuk : 1) Mengkaji karakteristik sosial ekonomi keluarga nelayan di Kecamatan Pangandaran Kabupaten Ciamis.; 2) Menganalisis pola pengambilan keputusan dan pembagian kerja antara suami dan istri pada keluarga nelayan di sektor domestik dan publik.

Penelitian ini menggunakan metode survey. Responden terdiri dari 30 keluarga nelayan. Data dianalisis secara deskriptif untuk membuat gambaran secara sistematis, faktual dan akurat mengenai fakta-fakta, sifat-sifat serta hubungan fenomena yang diteliti secara objektif.

Hasil penelitian menunjukkan bahwa tingkat pendidikan sebagian besar keluarga nelayan termasuk dalam kategori rendah. Persepsi tentang gender pada keluarga nelayan secara umum menggambarkan bahwa tugas utama istri adalah mengurus rumah tangga, tetapi boleh membantu suami dalam mencari nafkah keluarga; sedangkan tanggung jawab mencari nafkah utama tetap merupakan tugas suami. Pengambilan keputusan yang menyangkut aktivitas domestik dan publik dalam keluarga nelayan tidak mengikuti pola tertentu secara khusus terpusat pada suami atau istri, tetapi memiliki pola yang menyebar
\end{abstract}


antara suami dan istri. Pembagian kerja yang menyangkut aktivitas domestik lebih banyak dilakukan oleh istri. Sedangkan pembagian kerja yang berkaitan dengan aktivitas publik menyebar antara suami dan istri.

Kata kunci : gender, pembagian kerja, pengambilan keputusan

\section{PENDAHULUAN}

Rumah tangga nelayan sudah lama diketahui tergolong dalam rumah tangga miskin, disamping rumah tangga petani sempit, buruh tani dan pengrajin (Sayogyo, 1991). Oleh Smith dalam lqbal (2004) masyarakat (community) nelayan digambarkan dengan ciri rendahnya tingkat kehidupan (low income and low standar of living) masyarakatnya. Ciri-ciri kemiskinan sangat nampak pada masyarakat nelayan. Hal tersebut dapat dilihat pada pola hidup dan ketersediaan papan mereka yang memprihatinkan. Tidak hanya Smith, beberapa hasil penelitian yang lain seperti Pranadji, dkk dalam lqbal (2004) juga menghasilkan kesimpulan yang tidak berjauhan,bahwa standar hidup masyarakat nelayan berada di bawah standar hidup yang layak.

Dengan semakin berkembangnya dan beragamnya sektor lain di luar perikanan, semakin banyak memberi pilihan bagi masyarakat setempat untuk mendapatkan hasil tambahan di luar sektor utama. Para nelayan dapat memanfaatkan kesempatan tersebut untuk mencari tambahan penghasilan guna menutupi kebutuhan sehari-hari (lqbal, 2002). Meski demikian, rumah tangga nelayan harus menggunakan beragam strategi untuk mendapatkan peluang-peluang tersebut, sesuai dengan keahlian yang dimiliki dan orientasi ekonomi masing-masing.

Dalam menghadapi fenomena kemiskinan di masyarakat nelayan, maka keluarga nelayan tersebut harus mampu mengelola sumberdaya yang mereka miliki dengan seefektif dan seefisien mungkin agar kesejahteraan keluarga sebagai tujuan jangka panjang dapat tercapai. Terkait dengan sumberdaya yang dimiliki oleh keluarga tersebut, maka setiap potensi yang ada setidaknya dapat diikutsertakan dalam berbagai kegiatan baik di sektor domestik maupun publik. Dalam hal ini tidak hanya suami saja yang didorong untuk memaksimalkan perannya, tetapi juga istri. Istri dituntut berperan ganda, disamping sebagai pengurus rumah tangga, istri dituntut pula untuk membantu suami sebagai pencari nafkah untuk menambah pendapatan

Menurut Kusnadi, et al (2006), istri nelayan merupakan salah satu potensi sosial yang cukup penting dalam pembangunan kawasan pesisir, hal tersebut dikarenakan beberapa pertimbangan pemikiran : 1) Dalam sistem pembagian kerja secara seksual pada masyarakat nelayan, istri nelayan mengambil peranan yang besar dalam kegiatan sosial ekonomi di darat, sementara laki-laki berperan di laut untuk mencari nafkah dengan menangkap ikan. Dengan kata lain, darat adalah ranah perempuan, sedangkan laut adalah ranah laki-laki; 2) Dampak dari sistem pembagian kerja di atas mengharuskan kaum perempuan pesisir untuk selalu terlibat dalam kegiatan publik, yaitu mencari nafkah keluarga sebagai antisipasi jika suami mereka tidak memperoleh penghasilan. Kegiatan melaut merupakan kegiatan yang spekulatif dan terikat oleh musim; 3) Sistem pembagian kerja masyarakat pesisir dan tidak adanya kepastian penghasilan setiap hari dalam rumah tangga nelayan telah menempatkan perempuan sebagai salah satu pilar penyangga kebutuhan hidup rumah tangga. Dengan demikian, dalam menghadapi kerentanan ekonomi dan kemiskinan masyarakat nelayan, pihak yang paling terbebani dan bertanggung jawab untuk mengatasi dan menjaga kelangsungan hidup rumah tangga adalah kaum perempuan, istri nelayan. 
Berdasarkan pemaparan di atas, tujuan dari penelitian ini adalah untuk :

1. Mengkaji karakteristik sosial ekonomi keluarga nelayan di Kecamatan Pangandaran Kabupaten Ciamis.

2. Menganalisis pola pengambilan keputusan dan pembagian kerja antara suami dan istri pada keluarga nelayan di sektor domestik dan publik.

\section{METODE PENELITIAN \\ Metode Pengumpulan Data}

Pengumpulan data dilakukan dengan metode survey. Populasi keluarga nelayan di lokasi penelitian adalah 253 keluarga. Untuk keperluan penelitian ini diambil keluarga nelayan yang terdiri dari pasangan suami istri yang memiliki minimal satu orang anak. Berdasarkan kriteria tersebut terdapat populasi sebanyak 104 keluarga nelayan. Kemudian sampel diambil dengan menggunakan teknik acak sederhana dan dipilih 30 unit keluarga nelayan. Yang menjadi responden penelitian ini adalah suami dan istri.

\section{Jenis Data}

Pada penelitian ini, jenis data yang dikumpulkan terdiri dari data primer dan data sekunder yang diperoleh dengan cara pengamatan, wawancara dan juga dokumentasi. Data primer yang akan dikumpulkan adalah data primer mencakup karakteristik keluarga, persepsi tentang gender, serta pola pembagian keputusan dan pembagian kerja yang dilakukan oleh keluarga nelayan. Data sekunder mencakup informasi geografi dan demografi lokasi penelitian.

\section{Analisis Data}

Dalam penelitian ini digunakan analisis deskriptif untuk menggambarkan mengenai persepsi tentang gender, serta pola pengambilan keputusan dan pembagian kerja berdasarkan gender yang dilakukan oleh keluarga nelayan

Untuk menganalisis perspektif gender berdasarkan pendekatan analisis Harvard dan Mosher yang diterapkan dalam pola pengambilan keputusan dan pembagian kerja dalam keluarga dilakukan re-skoring terhadap jawaban responden dengan skor sebagai berikut : 1) jika keputusan diambil hanya oleh istri saja atau suami saja; 2) jika istri atau suami terlibat dalam pengambilan keputusan, tetapi salah satu pihak (suami atau istri) lebih dominan; 3) jika pengambilan keputusan dilakukan secara bersama-sama oleh suami dan istri. Kemudian skor yang diperoleh dikompositkan menggunakan rumus (1), dan dibagi ke dalam tiga kategori perspektif rendah/bias gender (skor <33,3), perspektif sedang/perspektif gender (skor 33,4-66,7) dan perspektif tinggi/responsif gender (skor 66,8-100,0).

\section{HASIL DAN PEMBAHASAN}

\section{Karakteristik Keluarga}

Umur. Berdasarkan kelompok umur produktif, yaitu mulai umur 15 tahun - 64 tahun, maka dapat dikatakan sebagian besar responden berada pada kelompok usia produktif, yaitu 93 persen suami dan 100 persen istri. Pada usia produktif ini seharusnya kepala keluarga dan iatri masih mampu bekerja dengan giat untuk mencukupi nafkah bagi seluruh anggota keluarganya. Pekerjaan sebagai nelayan membutuhkan stamina fisik yang kuat. Pekerjaan 
sebagai nelayan juga biasanya dikerjakan dalam waktu yang cukup lama. Nelayan tradisional biasanya berangkat kerja pada pagi hari dan pulang pada sore atau malam hari.

Lama Pendidikan. Dilihat dari tingkat pendidikan, dapat dikatakan tingkat pendidikan responden tergolong rendah, bahkan banyak yang tidak pernah menempuh pendidikan di sekolah formal, sebagian besar responden (77 persen suami dan 87 persen istri) hanya lulusan sekolah dasar. Dari segi pendidikan luar sekolah pun, seluruh responden tidak pernah mendapatkan pendidikan semacam itu, sehingga mereka tidak memiliki keterampilan tertentu. Keadaan tersebut juga yang menyebabkan responden sulit untuk mendapatkan pekerjaan di sektor formal dan akhirnya mereka bekerja di sektor informal, dimana mereka mendapatkan penghasilan yang tidak menentu. Pendidikan adalah salah satu upaya untuk meningkatkan kesejahteraan masyarakat. Semakin tinggi pendidikan, maka semakin besar peluangnya untuk mendapatkan penghasilan yang lebih besar untuk memenuhi kebutuhan seluruh anggota keluarganya.

Besar Keluarga. Anggota keluarga responden berkisar antara 2 sampai 8 orang dengan rata-rata 5 orang, artinya rata-rata keluarga responden termasuk dalam kategori keluarga sedang. Pandangan yang kerap muncul di masyarakat menyatakan bahwa banyak anak banyak rejeki. Namun kini pandangan tersebut tampaknya sudah bergeser karena membesarkan anak ternyata tidak hanya cukup dengan mencukupi kebutuhan pangan. Anak memerlukan pendidikan yang baik dan pendidikan yang baik memerlukan biaya yang mahal.

\section{Persepsi Tentang Gender}

Menurut William dan Best (1990), persepsi tentang gender merupakan kepercayaan normatif tentang bagaimana seharusnya penampilan seorang laki-laki atau perempuan, apa yang seharusnya dikerjakan oleh laki-laki atau perempuan, dan bagaimana keduanya berinteraksi. Persepsi tentang gender diukur melalui 15 item pertanyaan untuk menilai pandangan normatif responden tentang bagaimana pembagian peran dalam rumah tangga antara suami dan istri, serta akses dan kontrol perempuan pada sektor domestik dan publik.

Sebagian besar responden menyatakan setuju dengan pernyataan perempuan tidak pantas berperan sebagai pemimpin rumah tangga; istri menempati posisi yang lebih rendah daripada suami sehingga wajar jika wewenang untuk mengambil keputusan ada di tangan suami; istri harus meminta ijin pada suami untuk beraktivitas di luar rumah, suami dan istri sama-sama berhak memiliki hak nama atas aset yang dimiliki; istri boleh membantu suami dalam mencari nafkah; suami tidak hanya bertugas mencari nafkah tetapi harus mau berbagi tugas memasak dengan istri; istri perlu terlibat dalam kegiatan atau organisasi sosial; perempuan berhak terlibat dalam kegiatan politik; perempuan berhak menjadi pemimpin dalam organisasi sosial; perempuan berhak memiliki akses terhadap lembaga kredit (Tabel 1).

Pandangan tersebut menggambarkan bahwa perempuan sebagai istri menyadari perannya secara tradisional, dengan memandang bahwa kedudukan istri dalam keluarga lebih rendah dari pada suami sehingga wajar jika wewenang untuk mengambil keputusan ada di tangan suami. Sebagian besar responden tetap menilai bahwa suami lah yang berkewajiban mencari nafkah dan istri bertanggung jawab dalam mengurus rumah tangga, dan tidak ingin bertukar posisi meskipun secara ekonomis menguntungkan. Namun di lain pihak istri juga ingin terlibat lebih jauh di sektor publik, hal tersebut terlihat dari pernyataan bahwa istri boleh membantu suami dalam mencari nafkah, istri boleh terlibat dalam organisasi sosial serta persepsi istri bahwa perempuan berhak mengakses dan mengontrol sumberdaya yang ada. 
Kebutuhan dan kesadaran istri untuk beraktivitas di luar rumah, terutama untuk membantu mencari nafkah bagi keluarga terlihat dari ketidaksetujuan sebagian besar responden terhadap pernyataan tugas istri adalah mengurus rumah tangga saja; keterlibatan dalam kegiatan di luar rumah akan menyebabkan pekerjaan rumah tangga terbengkalai. Keadaan ini menunjukkan bahwa perangkat aturan yang berlaku dalam masyarakat tentang perempuan dalam keluarga cukup membuka ruang publik bagi istri, asalkan istri tidak melupakan atau meninggalkan tugas utamanya dalam keluarga sebagai ibu rumah tangga.

Sebagian besar istri juga menyatakan keinginan adanya keseimbangan pembagian peran dalam melaksanakan tugas-tugas rumah tangga, seperti dalam pengasuhan dan perawatan anak, dimana suami perlu terlibat lebih jauh, meskipun tanggung jawab terbesar dalam mengurus anak dan mengurus rumah tangga tetap berada di tangan istri. Bila dikaitkan dengan konteks debat teoritis antara faham Struktural Fungsional dan Sosial Konflik tentang pembagian kerja dalam keluarga, dapat dikatakan bahwa persepsi responden mayoritas cenderung mengarah pada penjelasan teori fungsionalisme yang mementingkan pembagian kerja dalam keluarga.

Sebagian besar responden (80\%) menyatakan bahwa anak perempuan juga perlu menempuh pendidikan setinggi mungkin, responden tidak pernah membedakan tingkat pendidikan bagi anak perempuan dan anak laki-laki, oleh karena itu sebagian besar responden memandang penting pendidikan bagi anak perempuan. Harapan ini juga tercermin pada persepsi responden tentang status perempuan yang sudah menikah, menurut lebih dari separuh responden $(62 \%)$ hal tersebut tidak membuat perempuan sulit untuk mencari nafkah di luar rumah. Dengan tingkat pendidikan yang semakin baik anak perempuan diharapkan akan mendapatkan pekerjaan dan masa depan yang lebih baik dan tidak hanya berperan sebagai istri yang tinggal di rumah. 
Tabel 1. Sebaran responden berdasarkan persepsi tentang gender

\begin{tabular}{|c|c|c|}
\hline \multirow[b]{2}{*}{ Pernyataan } & \multicolumn{2}{|c|}{$(n=30)$} \\
\hline & $\begin{array}{c}\mathrm{S} \\
(\%)\end{array}$ & $\begin{array}{l}\text { TS } \\
(\%)\end{array}$ \\
\hline $\begin{array}{l}\text { Saya memandang perempuan tidak pantas berperan sebagai pemimpin } \\
\text { rumah tangga. }\end{array}$ & 93 & 7 \\
\hline $\begin{array}{l}\text { Istri menempati posisi yang lebih rendah dari suami, sehingga wajar jika } \\
\text { wewenang untuk mengambil keputusan ada di tangan suami }\end{array}$ & 60 & 40 \\
\hline $\begin{array}{l}\text { Tugas istri adalah mengurus rumah tangga saja dan tugas suami hanya } \\
\text { mencari nafkah bagi keluarga }\end{array}$ & 53 & 47 \\
\hline $\begin{array}{l}\text { Keterlibatan istri dalam sektor publik akan membuat pekerjaan rumah } \\
\text { tangga terbengkalai }\end{array}$ & 27 & 73 \\
\hline Pengasuhan dan perawatan anak merupakan tanggung jawab istri saja & 63 & 37 \\
\hline Perempuan tidak perlu berpendidikan tinggi & 20 & 80 \\
\hline Perempuan yang berpendidikan tinggi akan lebih sulit mendapatkan suami & 33 & 67 \\
\hline Perempuan yang sudah menikah sulit untuk bekerja di luar rumah & 33 & 67 \\
\hline Istri harus meminta ijin pada suami untuk beraktivitas di luar rumah & 90 & 10 \\
\hline $\begin{array}{l}\text { Suami dan istri sama-sama berhak memiliki hak nama atas aset yang } \\
\text { dimiliki }\end{array}$ & 70 & 30 \\
\hline Istri memiliki hak penuh dalam mengontrol keuangan rumah tangga & 83 & 17 \\
\hline $\begin{array}{l}\text { Istri dan suami memiliki kedudukan yang setara dalam hal pengambilan } \\
\text { keputusan dalam keluarga }\end{array}$ & 17 & 83 \\
\hline Istri boleh membantu tugas suami dalam mencari nafkah keluarga & 93 & 7 \\
\hline $\begin{array}{l}\text { Tugas utama istri mengurus rumah tangga dan tugas utama suami mencari } \\
\text { nafkah bagi keluarga, tetapi boleh bertukar peran apabila secara ekonomis } \\
\text { memang menguntungkan. }\end{array}$ & 50 & 50 \\
\hline Istri perlu terlibat dalam kegiatan atau organisasi sosial & 87 & 13 \\
\hline
\end{tabular}

\section{Pengambilan Keputusan Keluarga}

Deacon dan Firebough (1988) mengemukakan bahwa pengambilan keputusan merupakan proses yang mendasari semua fungsi manajemen sumberdaya keluarga. Hal ini berarti bahwa selama proses manajemen sumberdaya berlangsung, maka proses pengambilan keputusan juga terjadi.

Konsep kekuasaan atau wewenang dalam pengambilan keputusan digunakan untuk mengungkapkan kapasitas dari seseorang atau kelompok untuk membuat keputusan. Dalam keluarga. wewenang dapat didistribusikan secara seimbang atau tidak seimbang di antara anggota keluarga, terutama diantara suami dan istri.

\section{Pengambilan Keputusan Pada Aktivitas Domestik}

Dalam hal pengambilan keputusan di bidang pangan, hampir seluruh responden keluarga nelayan didominasi oleh istri. Pada dua per tiga responden pengambilan keputusan dalam hal mengatur menu dan cara pengolahan makanan dilakukan oleh istri saja tanpa melibatkan suami. Hasil ini sejalan dengan penelitian Saleha (2003), Prasetyo (2004) bahwa 
pengambilan keputusan dalam pengeluaran pangan dan urusan makanan atau pangan cenderung diambil atau didominasi oleh istri.

Pengambilan keputusan di bidang pendidikan pada hampir tiga per empat responden dilakukan oleh suami. Peran istri terlihat dominan dalam mengatur pengeluaran untuk pendidikan, namun dalam menentukan anak sekolah atau tidak, memilih tempat pendidikan dan mengatur jenjang pendidikan anak keputusan dibuat oleh suami. Sejala dengan temuan ini, hasil penelitian Asizah (2001) pada masyarakat Makasar dan Saleha (2003) pada keluarga nelayan di Kalimantan Timur, juga menjelaskan bahwa pengambilan keputusan dalam pendidikan anak lebih banyak dibuat oleh suami. Hal tersebut diduga berkaitan dengan kemampuan finansial keluarga untuk membiayai sekolah anak dan hal ini berkaitan dengan kontribusi suami sebagai pencari nafkah utama.

Pengambilan keputusan di bidang kesehatan pada lebih dua per tiga responden dilakukan bersama-sama oleh suami dan istri. Peran istri terlihat lebih dominan dalam mengatur pengeluaran di bidang kesehatan, meskipun untuk menentukan tempat berobat keputusan tetap diambil bersama-sama antara suami dan istri. Hal ini diduga karena kondisi kesehatan keluarga merupakan tanggungjawab bersama antara suami dan istri. Pengambilan keputusan di bidang keuangan pada separuh respondendibuat bersama-sama oleh suami dan istri.

Pada lebih dari separuh responden (53\%) keputusan untuk mencari pekerjaan sampingan diambil bersama-sama antara suami dan istri. Berdasarkan penuturan responden, hal ini berhubungan dengan siapa yang melakukan pekerjaan sampingan.

Keputusan untuk membuat perencanaan keuangan keluarga, serta keputusan menabung dilakukan secara bersama-sama antara suami dan istri. Jika ada uang berlebih, suami dan istri biasanya berdiskusi apakah uang itu akan ditabung atau digunakan untuk membeli barang-barang rumah tangga. Keputusan untuk mengatur pengeluaran keluarga tetap didominasi oleh istri, meskipun pada sebagian kecil keluarga responden pengambilan keputusan dalam mengatur keuangan keluarga dilakukan oleh suami saja

Pengambilan keputusan mengenai pemeliharaan rumah tangga pada sebagian besar responden (87\%) dilakukan bersama-sama oleh suami dan istri. Keputusan untuk mengadakan peralatan rumah tangga, membeli pakaian anggota keluarga dan pembagian tugas pemeliharaan rumah pada sebagian besar keluarga responden didominasi oleh istri, sedangkan keputusan untuk perbaikan bangunan rumah lebih didominasi dilakukan oleh suami.

Pengambilan keputusan mengenai bidang reproduksi pada sebagian besar keluarga $(93 \%)$. Pada sebagian besar keluarga responden, suami dan istri bersama-sama mengambil keputusan dalam menentukan jumlah anak dan menentukan jarak kelahiran; sedangkan dalam menentukan alat kontrasepsi yang digunakan, sebagian besar responden (80\%) menyatakan keputusan diambil dominan oleh istri, hal ini diduga karena pada umumnya yang menggunakan alat kontrasepsi adalah istri.

Secara keseluruhan, perspektif gender dalam pengambilan keputusan mengenai aktivitas di sektor domestik pada lebih dari separuh responden (57\%) termasuk dalam kategori sedang. Dari hasil analisis tersebut, dapat disimpulkan bahwa pada aktivitas domestik, pengambilan keputusan tidak selalu merupakan tanggung jawab di pihak istri saja, tetapi telah menjadi tanggung jawab bersama antara suami dan istri, meskipun pada bidangbidang tertentu seperti penyediaan makanan di rumah serta pengaturan berbagai macam pengeluaran keluarga tanggung jawab istri tetap lebih dominan. 
Tabel 2. Sebaran responden (\%) menurut perspektif gender dalam pengambilan keputusan mengenai aktivitas di sektor domestik

\begin{tabular}{lc}
\hline \multicolumn{1}{c}{ Perspektif Gender } & n (\%) \\
\hline Rendah / bias gender $(0-33,33 \%)$ & 0 \\
Sedang/berperspektif gender(33,34\%-66,67\%) & $\mathbf{5 7}$ \\
Tinggi / responsif gender $(66,68 \%-100 \%)$ & 43 \\
\hline Rata-rata skor & 65,82 \\
\hline
\end{tabular}

\section{Pengambilan Keputusan Pada Aktivitas Publik}

Pola pengambilan keputusan di sektor publik, khususnya pada aspek ekonomi lebih banyak didominasi oleh suami. Keputusan yang berhubungan dengan modal usaha perikanan (penetapan besarnya modal usaha, menambah atau mengurangi modal; dan keputusan untuk meminjam modal) lebih didominasi oleh suami.

Pengambilan keputusan untuk usaha non perikanan juga lebih banyak dibuat oleh suami, yang meliputi pemilihan jenis usaha (67\%), penetapan skala usaha (53\%) dan keputusan pelaksanaan usaha tersebut $(60 \%)$. Hal tersebut terjadi karena suami dianggap ebih mengerti mengenai hal-hal tersebut dan berkaitan pula dengan tanggung jawab untuk mencari nafkah lebih besar dilakukan oleh suami.

Pengambilan keputusan di bidang sosial kemasyarakatan pada lebih dua per tiga responden (70\%) dibuat bersama-sama oleh suami dan istri. Keputusan untuk mengikuti pengajian didominasi oleh istri, sedangkan keputusan untuk mengikuti arisan pada sebagian besar keluarga responden dilakukan oleh istri saja. Dalam kegiatan gotong royong dan selamatan keputusan pada sebagian besar keluarga responden dilakukan bersama-sama oleh suami dan istri karena keduanya ikut terlibat dalam kegiatan tersebut. Dalam mengikuti rapat warga, keputusan pada sebagian besar keluarga responden didominasi oleh suami, bahkan pada sebagian keluarga keputusan ini diambil oleh suami saja tanpa melibatkan istri.

Secara keseluruhan, perspektif gender dalam pengambilan keputusan mengenai aktivitas di sektor publik pada lebih dari separuh responden keluarga (63\%) (Tabel 3). Pengambilan keputusan di sektor publik memang cenderung didominasi oleh suami; istri lebih banyak terlibat dalam pengambilan keputusan di bidang sosial kemasyarakatan dibandingkan pada aktivitas ekonomi di bidang perikanan dan non perikanan.

Tabel 3. Sebaran responden (\%) menurut perspektif gender dalam pengambilan keputusan mengenai aktivitas di sektor publik

\begin{tabular}{lc}
\hline \multicolumn{1}{c}{ Perspektif Gender } & $\mathbf{n}(\%)$ \\
\hline Rendah / bias gender $(0-33,33 \%)$ & 17 \\
Sedang/berperspektif gender(33,34\%-66,67\%) & 63 \\
Tinggi / responsif gender $(66,68 \%-100 \%)$ & 20 \\
\hline Rata-rata skor & 47,50 \\
\hline
\end{tabular}




\section{Pembagian Kerja dalam Keluarga}

\section{Pembagian Kerja di Sektor Domestik}

Aktivitas keluarga nelayan yang menjadi responden dalam penelitian ini tidak jauh berbeda dengan masyarakat pada umumnya, dimana aktivitas domestik lebih banyak dilakukan oleh istri. Kegiatan mengurus anak pada sebagian besar keluarga (77\%) dilakukan oleh istri saja. Kegiatan memandikan, memberi makan dan minum, menjaga anak yang masih kecil, menurus anak usia sekolah pada sebagian besar keluarga $(83 \%)$ dilakukan oleh istri saja. Pada usia pra sekolah peranan istri lebih besar dibandingkan suami, hal ini dikarenakan kegiatan suami di sektor publik untuk mencari nafkah lebih besar dibanding istri sehingga waktu suami yang tersisa untuk pekerjaan mengurus anak menjadi lebih sedikit; namun jika ada anak yang sakit sebagian besar istri dan suami melakukan pekerjaan untuk mengurus anak yang sakit ini bersama-sama.

Pada lebih dari separuh responden (53\%) kegiatan membantu anak belajar dilakukan oleh istri saja. Jika anak sudah memasuki jenjang pendidikan SLTP atau SLTA istri dan suami biasanya membiarkan anak belajar sendiri, hal ini disebabkan oleh, tingkat pendidikan istri dan suami yang mayoritas hanya lulus sekolah dasar.

Kegiatan mengerjakan pekerjaan rumah tangga pada sebagian besar keluarga $(97 \%)$ dominan dilakukan oleh istri. Pekerjaan memasak dan melakukan pemeliharaan rumah tangga, sebagian besar dilakukan oleh istri saja, dan biasanya istri dibantu oleh anak perempuan yang sudah cukup besar (berumur $>10$ tahun). Jika ada anak yang sudah berkeluarga masih tinggal bersama orangtua, pekerjaan mengurus rumah tangga ini biasanya dikerjakan bergantian oleh istri dan anak / menantu perempuannya. Namun pada sebagian kecil keluarga responden, terdapat fenomena yang cukup menarik dengan adanya peran suami dalam membantu istri untuk pekerjaan domestik, seperti mengasuh anak atau membersihkan rumah. Suami biasanya ikut membantu pekerjaan rumah tangga pada saat sebelum pergi melaut. Kondisi ini biasanya terdapat pada keluarga muda atau keluarga dengan anakyang masih kecil, sedangkan pada keluarga yang telah memiliki anak yang cukup besar, pekerjaan rumah tangga biasanya dibantu oleh anak.

Secara keseluruhan perspektif gender dalam pembagian kerja di sektor domestik pada seluruh responden termasuk dalam kategori rendah atau bias gender (Tabel 4). Sebagian besar pekerjaan di sektor domestik memang dikerjakan oleh istri. Hasil analisis tersebut sejalan dengan penelitian yang dilakukan oleh Saleha (2003), yang menunjukkan bahwa pada sebagian masyarakat berlaku pola pembagian kerja di sektor domestik merupakan tanggung jawab istri, meskipun ditemukan juga beberapa kasus dimana suami bersedia berbagi pekerjaan dengan istri untuk melakukan tugas rumah tangga. Ihromi (1990) juga mengatakan bahwa pekerjaan di sektor domestik utamanya berada di pundak istri.

Tabel 4. Sebaran responden (\%) menurut perspektif gender dalam pembagian kerja di sektor domestik

Perspektif Gender n (\%)

Rendah / bias gender ( $0-33,33 \%)$

Sedang/berperspektif gender (33,34\%-66,67\%)

Tinggi / responsif gender $(66,68 \%-100 \%)$
100

0

0

Rata-rata skor

5,45 


\section{Pembagian Kerja di Sektor Publik}

Untuk aktivitas publik yang berhubungan dengan aspek ekonomi yang menyangkut kegiatan usaha perikanan tangkap lebih banyak dilakukan oleh suami. Kegiatan menyiapkan alat, pelaksanaan operasi penangkapan dan perbaikan alat secara umum lebih banyak dilakukan oleh suami saja, namun terkadang istri dan anak yang sudah dewasa juga ikut membantu. Peran istri selain ikut terlibat dalam kegiatan perikanan secara langsung, juga terlibat secara tidak langsung. Keterlibatan istri secara tidak langsung biasanya hanya sebatas pada penyediaan bekal untuk makan suami melaut, hal ini disebabkan kegiatan menyiapkan bekal masih terkait dengan tanggung jawab istri dalam hal penyediaan makanan.

Untuk kegiatan yang berkaitan dengan usaha pengolahan hasil perikanan lebih banyak dilakukan bersama-sama antara suami dan istri, seperti sortasi hasil tangkapan $(50 \%)$ dan kegiatan pembersihan ikan dan udang (57\%). Para istri biasanya melakukan pekerjaan tersebut setelah setelah suami pulang melaut, sehingga kegiatan tersebut dapat dilakukan bersama-sama dengan suami sambil membersihkan alat tangkap dan perahu.

Kegiatan pengolahan ikan sebagai pekerjaan sampingan, tidak dilakukan oleh semua keluarga responden. Proses pengolahan ikan lebih banyak dilakukan oleh istri saja (70\%). Kegiatan pembuatan ikan asin dilakukan dilakukan oleh istri pada pagi hari atau pada saat suami melaut. Kegiatan lain, seperti membuat terasi, menjemur ikan asin biasanya dilakukan oleh istri pada siang hari disela-sela mengerjakan tugas domestik.

Kegiatan pemasaran hasil tangkapan lebih banyak dilakukan oleh suami, karena biasanya nelayan langsung menjual hasil tangkapan sepulang melaut. Sebaliknya, kegiatan menjual hasil olahan lebih banyak dilakukan oleh istri (83\%) karena sejak awal usaha pengolahan lebih banyak dilakukan oleh istri. Hal ini sejalan dengan hasil penelitian Saleha (2003) pada keluarga nelayan di Kalimantan Timur.

Semakin tumbuhnya sektor informal, mendorong pola nafkah ganda di komunitas masyarakat nelayan. Pekerjaan di bidang non perikanan pada separuh responden (50\%) dilakukan oleh suami maupun istri. Pekerjaan sebagai buruh bangunan, usaha bengkel mesin perahu lebih banyak dilakukan oleh suami. Kegiatan berdagang lebih banyak dilakukan oleh istri. Pekerjaan berdagang lebih banyak dilakukan oleh istri saja. Istri biasanya membuka warung di rumah atau berdagang makanan kecil-kecilan yang dijual dengan cara berkeliling desa. Bagi keluarga yang memiliki anak yang telah dewasa, biasanya anak juga ikut terlibat dalam kegiatan mencari nafkah dengan bekerja di luar sektor perikanan.

Kegiatan di luar sektor perikanan ini ditujukan untuk menambah pendapatan keluarga, karena pendapatan dari hasil menangkap ikan dirasakan tidak cukup untuk memenuhi kebutuhan keluarga. Hasil penelitian Sitorus (1992) menyebutkan bahwa peranan wanita dalam ekonomi rumah tangga nelayan miskin tidak terbatas pada aspek sumbangan uang tunai saja, tetapi juga mencakup aspek manajemen ekonomi rumah tangga. Manajemen keuangan rumah tangga nelayan miskin itu sepenuhnya berada di tangan istri.

Kegiatan di bidang sosial kemasyarakatan pada lebih dari separuh responden (53\%) dilakukan bersama-sama oleh suami maupun istri. Kegiatan pengajian, arisan, PKK serta Posyandu lebih banyak diikuti oleh istri. Kegiatan pengajian terdiri dari pengajian istri-istri dan pengajian bapak-bapak yang dilaksanakan dalam waktu yang berbeda di mesjid atau mushola yang tersebar di tiap RW, namun kegiatan ini lebih banyak dilakukan oleh istri. Dalam kegiatan arisan persentase istri yang ikut dan tidak ikut dalam kegiatan ini hampir berimbang. Sebagian istri yang mengikuti arisan mengatakan bahwa arisan itu seperti 
menabung, namun karena terbatasnya pendapatan sebagian istri lainnya memilih tidak ikut arisan, karena tidak memiliki uang untuk membayar arisan. Manfaat ekonomi yang diperoleh dari kegiatan arisan ini berkenaan dengan terbukanya kemungkinan untuk membiayai kebutuhan yang biayanya agak besar. Penerimaan dari arisan bisanya dimanfaatkan untuk keperluan pendidikan anak, dan membeli perabotan. Dalam kegiatan Posyandu sebagian besar istri menyatakan tidak terlibat dalam kegiatan tersebut, karena sudah tidak memiliki anak usia balita.

Kegiatan gotong royong biasanya dilakukan untuk membangun fasilitas bersama, seperti membangun mushola atau memperbaiki jalan desa. Kegiatan ini lebih banyak diikuti oleh suami, keterlibatan istri sebatas menyediakan makanan bagi para suami yang ikut kerja bakti yang dilakukan secara bergotong royong juga. Dalam kegiatan selamatan atau perayaan lain istri bersama dengan suami ikut terlibat membantu penyelenggaraan acara tersebut. Jika ada tetangga atau kerabat yang hendak menyelenggarakan hajatan istri dan suami sama-sama turut membantu.

Secara keseluruhan perspektif gender dalam pembagian kerja di sektor publik pada separuh responden termasuk dalam kategori sedang. Kegiatan di bidang perikanan dan non perikanan lebih didominasi oleh suami, karena suami memiliki tanggung jawab yang lebih besar dalam mencari nafkah bagi keluarganya, istri turut terlibat dalam kegiatan sosial kemasyarakatan.

Tabel 5. Sebaran responden (\%) menurut perspektif gender dalam pembagian kerja di sektor publik

\begin{tabular}{lc}
\hline \multicolumn{1}{c}{ Perspektif Gender } & n (\%) \\
\hline Rendah / bias gender (33,34\%-66,67\%) & 7 \\
Sedang / berperspektif gender $(0-33,33 \%)$ & 50 \\
Tinggi/responsif gender $(66,68 \%-100 \%)$ & 43 \\
\hline Rata-rata skor & 61,55 \\
\hline
\end{tabular}

\section{KESIMPULAN DAN SARAN}

\section{Kesimpulan}

1. Karakteristik keluarga menunjukkan bahwa tingkat pendidikan sebagian besar keluarga nelayan termasuk dalam kategori rendah. Hal ini membuat keluarga nelayan sulit untuk mengembangkan dirinya.

2. Persepsi tentang gender pada keluarga nelayan secara umum menggambarkan bahwa tugas utama istri adalah mengurus rumah tangga, tetapi boleh membantu suami dalam mencari nafkah keluarga; sedangkan tanggung jawab mencari nafkah utama tetap merupakan tugas suami.

3. Pengambilan keputusan yang menyangkut aktivitas domestik dan publik dalam keluarga nelayan tidak mengikuti pola tertentu secara khusus terpusat pada suami atau istri, tetapi memiliki pola yang menyebar antara suami dan istri. 
4. Pembagian kerja yang menyangkut aktivitas domestik lebih banyak dilakukan oleh istri. Sedangkan pembagian kerja yang berkaitan dengan aktivitas publik menyebar antara suami dan istri.

\section{Saran}

1. Secara umum, persepsi tentang gender yang dianut keluarga nlayan cukup memberikan peluang bagi istri untuk memauki ruang publik, hanya saja kondisi ini belum dimanfaatkan secara optimal untuk peningkatan kualitas sumberdaya keluarga dalam memanfaatkan daya dukung sumberdaya alam khususnya di bidang perikanan. Sehubungan dengan hal tersebut, dirasakan perlu kegiatan pelatihan teknis dan manajemen pengelolaan usaha kecil di bidang pengolahan hasil perikanan yang bertujuan mengoptimalkan peran istri dalam meningkatkan kualitas sumberdaya keluarga.

2. Penelitian ini belum memberikan gambaran secara terpisah mengenai kehidupan keluarga nelayan juragan dan nelayan buruh. Untuk itu, pada penelitian selanjutnya disarankan untuk menganalisis mengenai kehidupan keluarga nelayan juragan dan buruh, terutama yang berkaitan dengan tema analisis gender.

\section{DAFTAR PUSTAKA}

Azzachrawani. 2004. Kontribusi Perempuan Terhadap Pendapatan Keluarga dan Dampaknya Terhadap Kepuasan Keluarga [tesis]. Bogor : Program Pascasarjana Institut Pertanian Bogor.

Deacon RE, Firebaugh FM. 1988. Family Resources Management Principles and Aplication. Boston : Allyn and Bacon Inc.

lqbal, Moch. 2004. Strategi Nafkah Rumah Tangga Nelayan. [Tesis]. Bogor: Institut Pertanian Bogor.

Kusnadi. 2003. Akar Kemiskinan Nelayan. LKiS. Yogyakarta.

Kusnadi, et al. 2006. Perempuan Pesisir. LKiS. Yogyakarta.

Puspa AR. 2007. Kajian ketahanan keluarga petani : pengambilan keputusan istri dan hubungannya dengan kesejahteraan keluarga. Skripsi. Program Studi Gizi Masyarakat dan Sumberdaya Keluarga. Fakultas Pertanian. Bogor : Institut Pertanian Bogor.

Prasetyo. A. 2004. Analisis Jender Terhadap Strategi Ketahanan Hidup Keluarga Melalui Manajemen Keuangan Pada Keluarga Nelayan. Skripsi. Program Studi Gizi Masyarakat dan Sumberdaya Keluarga. Fakultas Pertanian. Bogor : Institut Pertanian Bogor.

Saleha, Qariah. 2003. Manajemen Sumberdaya Keluarga : Suatu Analisis Gender dalam Kehidupan Keluarga Nelayan di Pesisir Bontang Kuala, Kalimantan Timur. Tesis. Program Pascasarjana Institut Pertanian Bogor

Sitorus, Felix. 1992. Strategi Ekonomi Rumah Tangga Nelayan Miskin dalam Bunga Rampai Sosiologi Keluarga. Yayasan Obor Indonesia. Jakarta.

William JE, Best DL. 1990. Sex and Self Viewed Cross Culturally. California/London/New Delhi : Sage Publication. 